\title{
Analysis and Synthesis of Distributed Real-Time Embedded Systems
}

Pop, Paul; Eles, Petru; Peng, Zebo

Publication date:

2004

Document Version

Publisher's PDF, also known as Version of record

Link back to DTU Orbit

Citation (APA):

Pop, P., Eles, P., \& Peng, Z. (2004). Analysis and Synthesis of Distributed Real-Time Embedded Systems. (22 ed.) Kluwer Academic Publishers.

\section{General rights}

Copyright and moral rights for the publications made accessible in the public portal are retained by the authors and/or other copyright owners and it is a condition of accessing publications that users recognise and abide by the legal requirements associated with these rights.

- Users may download and print one copy of any publication from the public portal for the purpose of private study or research.

- You may not further distribute the material or use it for any profit-making activity or commercial gain

- You may freely distribute the URL identifying the publication in the public portal

If you believe that this document breaches copyright please contact us providing details, and we will remove access to the work immediately and investigate your claim. 


\section{Analysis and Synthesis of Distributed Real-Time Embedded Systems}

By

Paul Pop, Petru Eles and Zebo Peng

Linköping University, Sweden

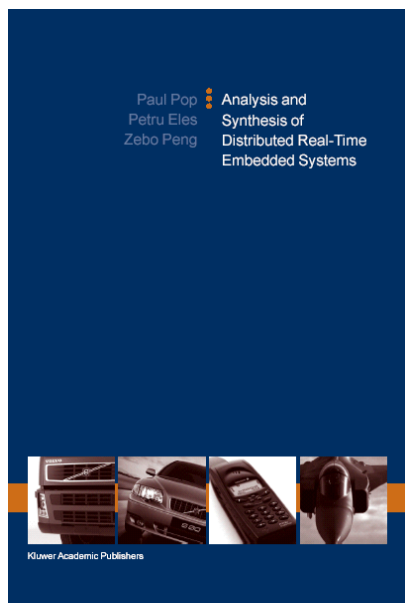

Embedded computer systems are now everywhere: from alarm clocks to PDAs, from mobile phones to cars, almost all the devices we use are controlled by embedded computers. An important class of embedded computer systems is that of hard real-time systems, which have to fulfill strict timing requirements. As real-time systems become more complex, they are often implemented using distributed heterogeneous architectures.

Analysis and Synthesis of Distributed Real-Time Embedded Systems addresses the design of realtime applications implemented using distributed heterogeneous architectures. The systems are heterogeneous not only in terms of hardware components, but also in terms of communication protocols and scheduling policies. Regarding this last aspect, time-driven and event-driven systems, as well as a combination of the two, are considered. Such systems are used in many application areas like automotive electronics, real-time multimedia, avionics, medical equipment, and factory systems. The proposed analysis and synthesis techniques derive optimized implementations that fulfill the imposed design constraints. An important part of the implementation process is the synthesis of the communication infrastructure, which has a significant impact on the overall system performance and cost.

Analysis and Synthesis of Distributed Real-Time Embedded Systems considers the mapping and scheduling tasks within an incremental design process. To reduce the time-to-market of products, the design of real-time systems seldom starts from scratch. Typically, designers start from an already existing system, running certain applications, and the design problem is to implement new functionality on top of this system. Supporting such an incremental design process provides a high degree of flexibility, and can result in important reductions of design costs.

Analysis and Synthesis of Distributed Real-Time Embedded Systems will be of interest to advanced undergraduates, graduate students, researchers and designers involved in the field of embedded systems.

For more information

visit our website 


\section{Visit our website: www.wkap.nl}

Your electronic gateway to Kluwer. It's free, it's current, and it's all available on your computer We hope you will bookmark this site to make future visits even easier.

Enter the Complete Catalogue and look up information on publications in specific subject areas, including tables of contents and order forms for all Kluwer titles.

Tailor your search for information on any Kluwer publication using our dynamic search form.

\section{阿 kluwer}

the language of science

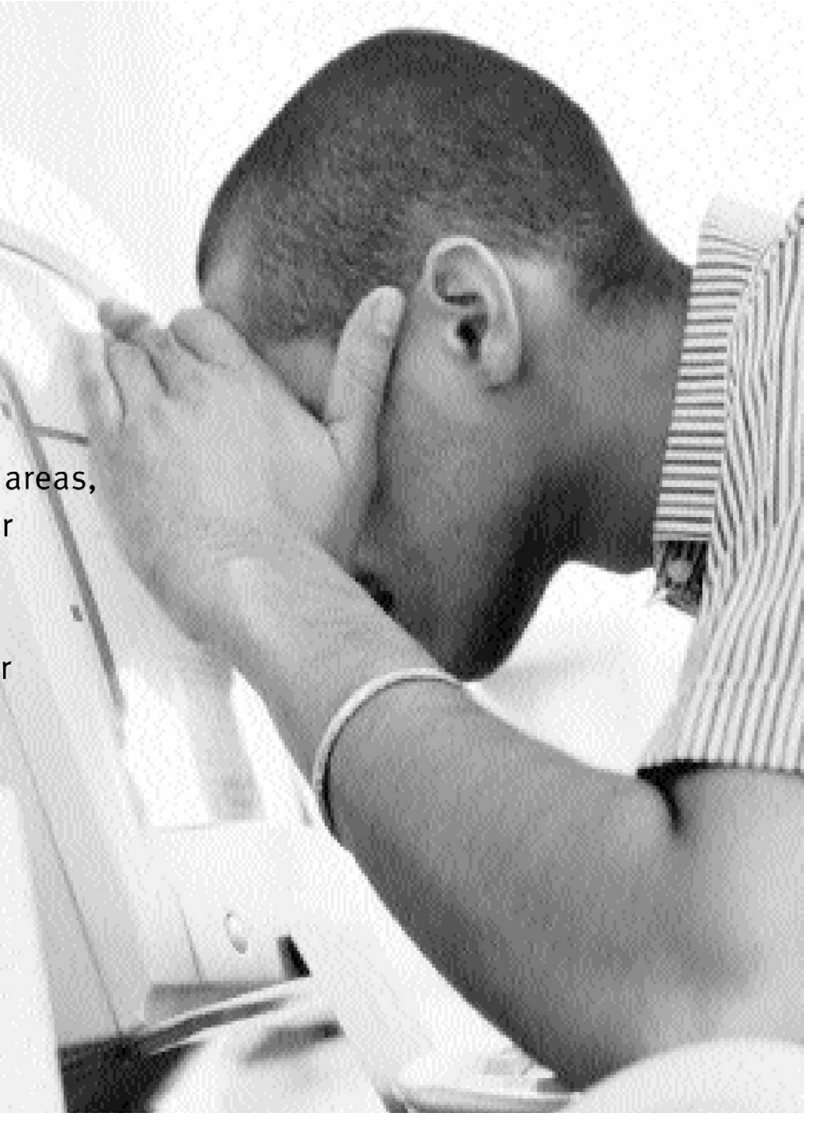

Q.

Order form: Analysis and Synthesis of Distributed Real-Time Embedded Systems by Pop et al.

$\square \quad$ Please send cop(y) (ies) Hardbound 2004, 326 p., ISBN: 1-4020-2872-5, € 114.00 / US\$139.00 / £ 79.00

$\square \quad$ Please send eBook, ISBN 1-4020-2873-3, € 114.00 / US\$139.00 / £ 79.00

* fill in the VAT number of your institute/company in the appropriate space on the order form. CA, CO (as from July 1, 2004), MA, MO and NY residents, please add sales tax. Canadian residents, please add 7\% GST. Customers in the Netherlands, please add $6 \%$ VAT tax. Postage \& Handling charges apply.
$\square$ Payment enclosed to the amount of $\square$ Please invoice
$\square \mathrm{me}$
$\square$ my institution/company
$\square$ Please charge my credit card account $\square$ American Express
$\square$ Visa
$\square$ MasterCard / Eurocard

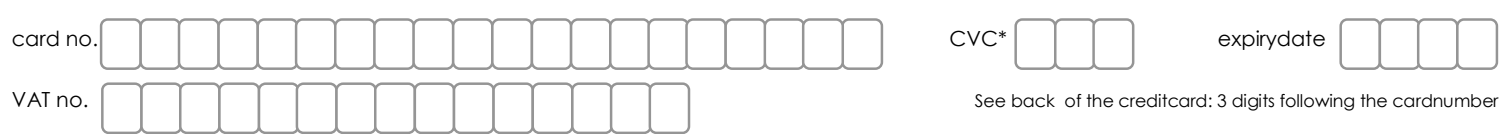

Organization

